\title{
Standardization of Isolation Methodology for Early Detection and Estimation of Major Hot Spots of Dematophora necatrix, Causing White Root Rot of Apple in Himachal Pradesh
}

\author{
Joginder Pal* and Satish K. Sharma
}

\begin{abstract}
Department of Plant Pathology, Dr. Y.S. Parmar University of Horticulture and Forestry, Nauni, Solan -173230, Himachal Pradesh, India
\end{abstract}

*Corresponding author

\begin{tabular}{|l|}
\hline Key w o r d s \\
$\begin{array}{l}\text { Root rot, Leaf discs, } \\
\text { Microscopic } \\
\text { examination }\end{array}$ \\
\hline Article Info \\
\hline $\begin{array}{l}\text { Accepted: } \\
\text { 15 December } 2018 \\
\text { Available Online: } \\
\text { 10 January } 2019\end{array}$ \\
\hline
\end{tabular}

A B S T R A C T

\section{Introduction}

White root rot disease caused by Dematophora necatrix Hartig [Rosellinia necatrix (Hartig) Berl.] is one of the most destructive diseases affecting apple orchards in temperateand subtropical regions of the world. In India, the fungus has been considered as the major constraints causing extensive losses in apple production especially in Himachal Pradesh, as the state is well recognized as the apple state of country. The pathogen is a typical soil-inhabiting fungus, survive dormant in soil during unfavourable condition and cause severe losses in nurseries as well in orchards. The disease was first 
recorded in 1883 from Germany (Hartig, 1883) and 1891 from France on grapes (Viala, 1891). On apple, the first occurrence of this devastating disease was observed in 1900 from Norwich, and subsequently in Canterberry by Salmon and Wormald (1913). $R$. necatrix, the perfect stage of fungus was identified as the causal organism leading to the death of apple trees in a garden at Winscombie, Sommerset (Nattrass, 1927). In India, the disease was first reported from Uttarakhand hills by Singh in 1929 (Bose and Sindhan, 1976). Agarwala (1961) observed its occurrence in apple orchard of Himachal Pradesh in a very high proportion causing severe and ultimately death of grown up plants.

The teleomorphic stage of the fungus is not known to occur in India till date. The fungus has a wide host range found associated to about 158 plant species belonging to over 45 families (Ito and Nakamura, 1984) comprising of fruit plants, forest trees and vegetable and field crops. The pathogen survives in the form of mycelium or sclerotia in the infected roots. The infection of new roots takes place by the fungal mycelium present in the sol on debris or by the contact of new plant roots with the old dead roots. The disease is more serious in water logged acidic soils. The pathogen mainly attacks the underground part of the trees. The lateral roots turn dark brown and are covered with greenish gray or white mycelial mat and with the progress of disease all the roots are attacked and fibrous root system disappears. Whitish mycelial mat like fungal growth is visible during monsoon on the affected parts. The affected plants show bronzing of the leaves and progressive decline and ultimately die within 2-3 years of infection. Management of root rot is often considered tedious because of deep seated infection. It is very difficult to make the reach of applied remedial measures up to the point of infection. Therefore, keeping in view the importance of this devastating disease on apple cultivation, the present study was conducted with the objective to standardize the technique which could help out in early detection of pathogen and also to find out the major hot spots of root rot in Himachal Pradesh.

\section{Materials and Methods}

Undoubtedly, many researchers had developed several techniques over the period of time for estimation of $R$. necatrix population keeping in view the importance of pathogen. Notably, advancement in molecular techniques alleviated some of the issues associated with the detection and estimation. Although, these modern techniques seems to be rapid and highly sensitive in detecting $R$. necatrix by employing real time scorpion-PCR, but are too expensive. However, the development of a quantitative detection method will facilitate studies to determine inoculum threshold levels, and to ascertain some still unclear epidemiological aspects that are necessary for the development of white root rot disease due to non-sporulating nature of the fungus $D$. necatrix as compared to its teleomorph $R$. necatrix (Schena and Ippolito, 2003).

For assessment of $R$. necatrix, trapping technique using avocado leaf discs was described earlier by Sztejnberg et al., (1987) but has proven laborious, time consuming and non realible due to its inconsistency in the effective and quick isolation of pathogen from soil. These constraints have encouraged the search for alternative approaches. Therefore, technique was further modified and standardized for ease in estimation of $D$. necatrix causing root rot of apple. The baiting step of existing technique was replaced with adding up different baits followed by microscopic examination. Each treatment was replicated thrice in completely randomized design (CRD). Different steps for estimation 
of D. necatrix population from soil are described as below:

\section{Soil collection}

To know the prevalence of white root disease a survey was conducted in three major apple

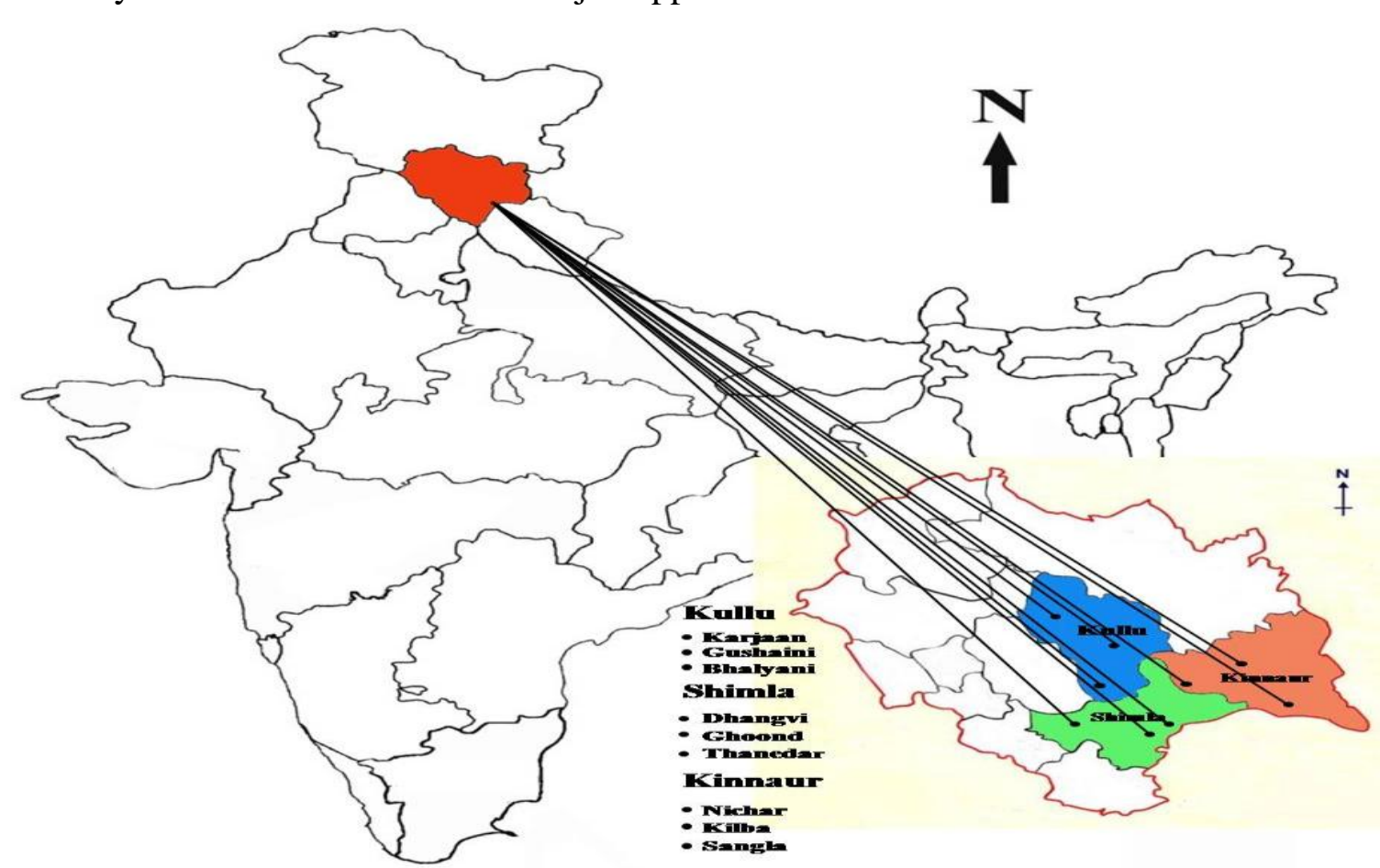

growing district viz., Kullu, Shimla and Kinnaur of Himachal Pradesh. After conducting survey, samples of soils near infected tree basin of depth $20-30 \mathrm{~cm}$ were collected in polypropylene bags from three most infected locations in each district.
Soil sieving: Partially dried soil was sieved by passing through 2 to $2.5 \mathrm{~mm}$ sieve.

Air drying: Sieved soil samples were air dried in shade at room temperature for 24 hours on sterilized filter paper.

Mix plating: The soil samples were thoroughly mixed, of which $200 \mathrm{~g}$ of soil was taken out and added to the $20 \mathrm{~cm}$ diameter glass Petri plate.

Baiting: Petri plates were then embedded with twenty baits such as avocado leaf discs, kiwi leaf discs and apple leaf discs (1.5 cm each) separately.

These leaf discs were placed in close contact with the infected soil and plates were then covered immediately.
Moistening: Soil in Petri plates was moistened with sterile distilled water using atomizer. The plates were further moistened at three days interval or depending upon moisture level of soil.

Incubation: Covered plates were then incubated at room temperature $\left(20-25{ }^{\circ} \mathrm{C}\right)$ for 15 days to allow the pathogen to infect and grow on the leaf discs. The incubated plates were kept as such until more or less whitish layer of mycelium appeared on respective leaf discs.

Microscopic examination: Finally, mycelium from infected or colonized leaf discs were taken out by scratching with sterilized needle and placed on clean glass slide for microscopic examination. 
Per cent infection of baits was calculated as given below:

Infection of baits $(\%)=$

Number of infected baits

------------------------------ $\times 100$

Total number of baits

\section{Results and Discussion}

In the present investigation, attempts were made to standardize isolation methodology for early detection and also to determine the major hot spots of white root rot in Himachal Pradesh. The perusal of data (Table 1) reveals that in all infected soil samples collected from infected sites of three districts, baits of kiwi leaf discs showed maximum mean infection (19.44\%) of $D$. necatrix followed by avocado $(18.89 \%)$ and apple leaf discs (8.89\%). Trapping nature of kiwi leaf disc may be attributed to the highly hairy character of leaves which can easily trap the pathogen from soil. Avocado leaf discs also showed good colonization behavior but cannot be employed due to its non availability in the state (Fig. 1).

Table.1 In vitro evaluation of different leaf baits for the estimation of infection and hot spots of white root rot pathogen of apple in Himachal Pradesh

\begin{tabular}{|c|c|c|c|c|c|}
\hline \multirow[t]{2}{*}{ District } & \multirow[t]{2}{*}{ Sites } & \multicolumn{3}{|c|}{ Infection of baits (\%) } & \multirow[t]{2}{*}{ Mean (\%) } \\
\hline & & $\begin{array}{l}\text { Kiwi leaf } \\
\text { discs }\end{array}$ & $\begin{array}{l}\text { Apple leaf } \\
\text { discs }\end{array}$ & $\begin{array}{c}\text { Avocado leaf } \\
\text { discs }\end{array}$ & \\
\hline \multirow[t]{3}{*}{ Kullu } & Karjaan & $\begin{array}{c}25.00 \\
(29.91)\end{array}$ & $\begin{array}{c}8.33 \\
(16.59)\end{array}$ & $\begin{array}{c}13.33 \\
(21.33)\end{array}$ & $\begin{array}{c}15.56 \\
(22.61)\end{array}$ \\
\hline & Gushaini & $\begin{array}{c}15.00 \\
(22.59)\end{array}$ & $\begin{array}{c}10.00 \\
(18.43)\end{array}$ & $\begin{array}{c}16.67 \\
(24.04)\end{array}$ & $\begin{array}{c}13.89 \\
(21.68)\end{array}$ \\
\hline & Bhalyani & $\begin{array}{c}28.33 \\
(32.08)\end{array}$ & $\begin{array}{c}8.33 \\
(16.59)\end{array}$ & $\begin{array}{c}21.67 \\
(27.70)\end{array}$ & $\begin{array}{c}19.44 \\
(25.46)\end{array}$ \\
\hline \multirow[t]{3}{*}{ Shimla } & Dhangvi & $\begin{array}{c}16.67 \\
(24.04)\end{array}$ & $\begin{array}{c}6.67 \\
(14.75)\end{array}$ & $\begin{array}{c}20.00 \\
(26.44)\end{array}$ & $\begin{array}{c}14.44 \\
(21.74)\end{array}$ \\
\hline & Ghoond & $\begin{array}{c}23.33 \\
(28.84)\end{array}$ & $\begin{array}{c}8.33 \\
(16.59)\end{array}$ & $\begin{array}{c}30.00 \\
(33.15)\end{array}$ & $\begin{array}{c}20.56 \\
(26.19)\end{array}$ \\
\hline & Thanedar & $\begin{array}{c}15.00 \\
(22.59)\end{array}$ & $\begin{array}{c}5.00 \\
(12.92)\end{array}$ & $\begin{array}{c}13.33 \\
(23.85)\end{array}$ & $\begin{array}{c}11.11 \\
(19.78)\end{array}$ \\
\hline \multirow[t]{3}{*}{ Kinnaur } & Nichaar & $\begin{array}{c}16.67 \\
(24.04)\end{array}$ & $\begin{array}{c}6.67 \\
(14.75)\end{array}$ & $\begin{array}{c}15.00 \\
(22.78)\end{array}$ & $\begin{array}{c}12.78 \\
(20.52)\end{array}$ \\
\hline & Sangla & $\begin{array}{c}15.00 \\
(22.59)\end{array}$ & $\begin{array}{c}5.00 \\
(12.92)\end{array}$ & $\begin{array}{c}16.67 \\
(21.14)\end{array}$ & $\begin{array}{c}12.22 \\
(18.88)\end{array}$ \\
\hline & Kilba & $\begin{array}{c}20.00 \\
(26.44)\end{array}$ & $\begin{array}{c}21.67 \\
(27.58)\end{array}$ & $\begin{array}{c}23.33 \\
(28.77)\end{array}$ & $\begin{array}{c}21.67 \\
(27.60)\end{array}$ \\
\hline Mean & & $\begin{array}{c}19.44 \\
(25.90)\end{array}$ & $8.89(16.79)$ & $18.89(25.46)$ & \\
\hline $\mathrm{CD}_{0.05}$ & & $\begin{array}{r}\text { Si } \\
\text { Leaf } \\
\text { Sites }(\mathrm{S}) \mathrm{X}\end{array}$ & $\begin{array}{l}(\mathrm{S})=2.97 \\
\mathrm{cs}(\mathrm{LD})=1.71 \\
\text { af discs }(\mathrm{LD})\end{array}$ & 5.14 & \\
\hline
\end{tabular}

Figures in the table are arc sign transformed values 
Fig.1 Plates showing the infection of D. necatrix on different leaf baits (kiwi, apple and avocado; left to right) in soil samples collected from major white root rot infected zones of Himachal Pradesh
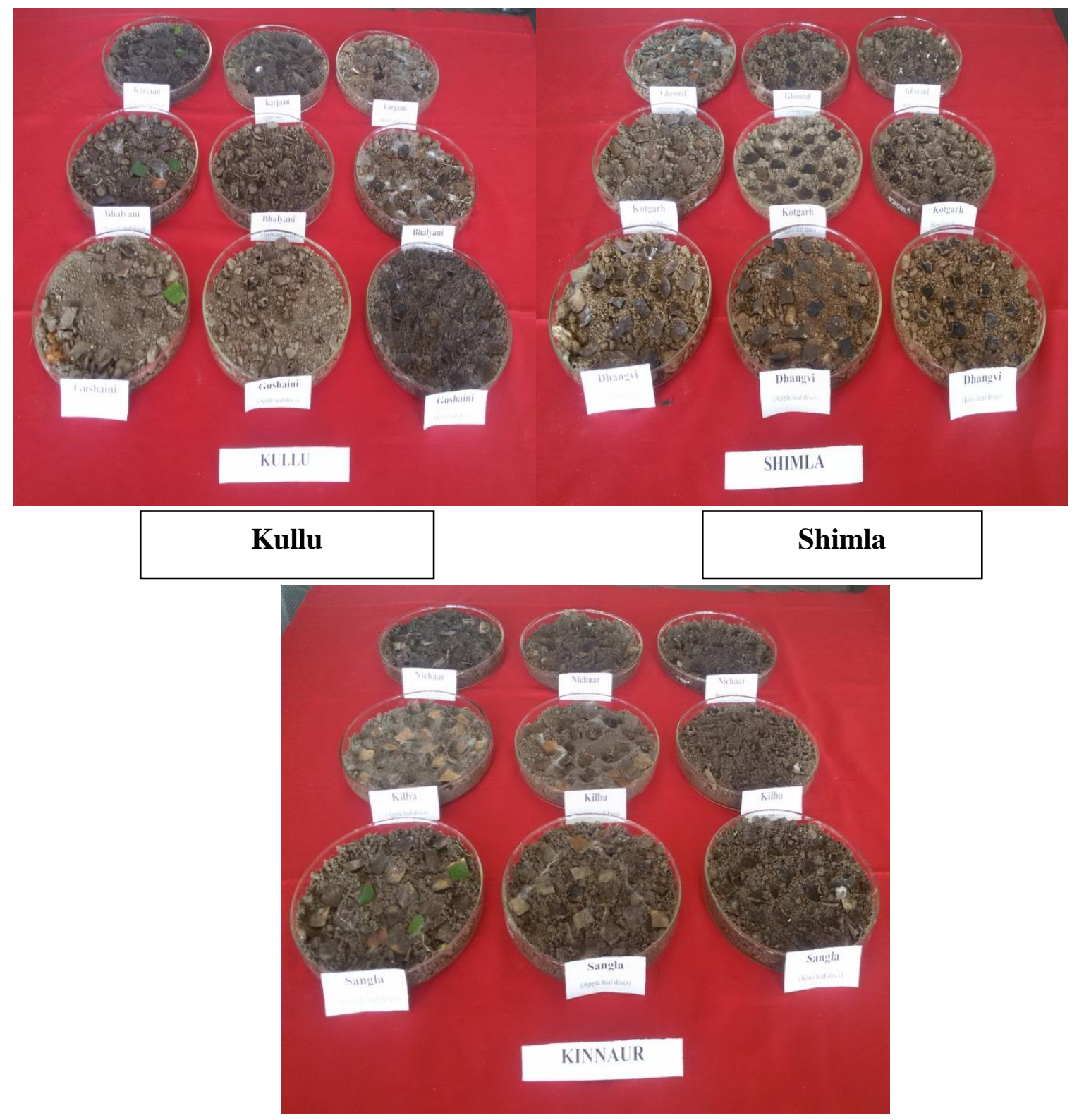

Kinnaur

Maximum infection of baits was observed in Ghoond area $(30.00 \%)$ of district Shimla by using avocado leaf discs followed by Bhalyani area $(28.33 \%)$ of district Kullu by using baits of kiwi. Whereas, minimum bait infection was recorded in Sangla area (5.00 $\%$ ) of district Kinnaur with apple leaf discs.
Overall, the maximum mean infection (21.67 $\%$ ) was observed in Kilba area of district Kinnaur followed by Ghoond $(20.56 \%)$ area of district Shimla and Bhalyani (19.44\%) area of district Kullu. However, least mean bait infection (11.11\%) was recorded in Sangla area of Kinnaur district. 
The leaf disc colonization method for trapping Rosellinia bunodes and $R$. necatrix from diseased cocoa roots and avocado roots has been utilized earlier by various workers for assessment of inoculums levels of this pathogen (Freeman et al., 1986; Freeman and Sztejnberg, 1992). Baits like avocado leaf disc (Sztejnberg et al., 1983), twigs of Populus sieboldii (Ito and Nakamura, 1984) have also been tried earlier for isolation of Rosellinia sp. from soil. Eguchi et al., (2009) have also established that baits of mulberry can be used for detecting Rosellinia necatrix at an early stage of infection from naturally infested sick soil in apple and pear orchards in Japan.

In conclusion, opportunistic soil borne pathogens such as D. necatrix (teleomorph Rosellinia spp.) are notoriously difficult to control once they manifest themselves. The bait twig method facilitated quicker diagnosis of $D$. necatrix during the early stages of the infection and can be employed to know the major hotspots of disease and subsequent selection of control measures. Moreover, the detection of $D$. necatrix infection on roots before aerial symptoms are observed would facilitate the application of control strategies during the early stages of the infection, avoiding tree death and further disease spread, which are major problems to overcome when managing white root rot disease. Baiting followed by microscopic examination has several advantages over direct plating technique because in baiting technique large quantity of soil can be tested even when pathogen are present in low population density. In addition, microscopic examination of mycelium from baits made identification easy and more confirmatory. From the aforesaid findings, it is deduced that Ghoond and Dhangvi in district Shimla, Bhalyani and Karjaan in district Kullu whereas, Kilba and Nichaar in district Kinnaur are the major hot spots of root rot disease. In addition, kiwi leaf discs, avocado leaf discs (if available) and to small extent apple leaf discs could be employed for quick detection and estimation of the major hot spots of root rot infecting areas in the state as well as country.

\section{References}

Agarwala, R.K. 1961. Problems of root rot in Himachal Pradesh and prospects of its control with antibiotics. Himachal Hort. 2: 171-178.

Bose, S.K. and Sindhan, S.G. 1976. Work on the diseases of the temperate fruits in UP and their control. Proceedings: All India Coordinated Fruit Improvement Project Workshop, Ranikhet pp. 491499.

Eguchi, N., Kondo, K.I. and Yamagishi, N.2009. Bait twig method for soil detection of Rosellinia necatrix, causal agent of white root rot of Japanese pear and apple, at an early stage of tree infection. J. Gen. Plant Pathol.75: 325330.

Freeman, S. and Sztejnberg, A. 1992. Rosellinia. In: Methods for research on soilborne phytopathogenic. L. L. Singleton, J. D. Mihail and C. M. Rush, eds. American Phytopathological Society Press, Minnesota, USA. pp. 7173.

Freeman, S., Sztejnberg, A., Chet, I. and Katan, J. 1986. Solar and biological control of white root rot disease in apple orchards caused by the soil borne fungus Rosellinia necatrix. Hassadeh 66: 1608-1613.

Hartig, R. 1883. Untermuchungen aus dem Forest rot amschen. Institut $\mathrm{Zu}$ Munchen 3: $95-141$.

Ito, S.I. and Nakamura, N. 1984. An outbreak of white root rot and its environmental conditions in the experimental arboretum. J. Jap. For. Soc. 66: 262267. 
Nattrass, R.M. 1927. The white root rot of fruit trees caused by Rosellinia necatrix (Hart.) Berl. Annual Report of Agricultural and Horticultural Research Station, Long Ashton, Bristol pp. 66-72.

Schena, L. and Ippolito, A. 2003. Rapid and sensitive detection of Rosellinia necatrix in roots and soils by real time Scorpion-PCR. Journal of Plant Pathology 85: 15-25.

Sztejnberg, A., Freeman, S., Chet, I., and Katan, J. 1987. Control of Rosellinia necatrix in soil and apple orchard by solarization and Trichoderma harziarum. Plant Dis. 71: 365-369.

Sztejnberg, A., Azaizia, H. and Chet, I. 1983. The possible role of phenolic compounds in resistance of horticultural crops to Dematophora necatrix Hartig. Journal of Phytopathology, 107: 318-326.

Viala, P. 1891. Monograph duepourridie (Dematophora) des vigens. Paris.

Salmon, E.S and Wormald, H. 1913. Report on Economic Mycology. Journal of South East Agriculture, 22: 453.

\section{How to cite this article:}

Joginder Pal and Satish K. Sharma. 2019. Standardization of Isolation Methodology for Early Detection and Estimation of Major Hot Spots of Dematophora necatrix, Causing White Root Rot of Apple in Himachal Pradesh. Int.J.Curr.Microbiol.App.Sci. 8(01): 661-667. doi: https://doi.org/10.20546/ijcmas.2019.801.074 